\title{
Geloof en kennis in die Heidelbergse Kategismus
}

\begin{abstract}
Author:
Sarel P. van der Walt ${ }^{1}$

Affiliation:

${ }^{1}$ Faculty of Theology, North-

West University, South Africa

Correspondence to:

Sarel van der Walt

Email:

sarel.vanderwalt@nwu.ac.za

Postal address:

PO Box 19846, Noordbrug

2522, South Africa

Dates:

Received: 14 Feb. 2013

Accepted: 29 July 2013

Published: 13 Sept. 2013

How to cite this article:

Van der Walt, S., 2013,

'Geloof en kennis in die Heidelbergse Kategismus', In die Skriflig/In Luce Verbi 47(2), Art. \#702, 9 pages. http://dx.doi.org/10.4102/ ids.v47i2.702
\end{abstract}

\section{Copyright:}

(C) 2013. The Authors. Licensee: AOSIS

OpenJournals. This work is licensed under the

Creative Commons

Attribution License.

Read online:
Die wyse waarop die noue band tussen geloof en kennis verstaan moet word, figureer huidig steeds in teologiese debatte. In hierdie artikel word die verband wat deur vraag en antwoord 21 van die Heidelbergse Kategismus tussen geloof en kennis getrek word, bestudeer. In reaksie op die skolastiek van die laat-Middeleeue toe verintellektualisering van geloof besonder beklemtoon is, het die Reformasie 'n klaarblyklike gebalanseerde nuansering van die verband tussen geloof en kennis tot gevolg gehad. Veral Calvyn het 'n besondere bydrae hiertoe gelewer en het ' $n$ bepaalde invloed gehad op die formulering van geloof se kenniselement. Dit het ruimte gebied waarbinne Ursinus en die res van die betrokke kommissie hierdie unieke verband kon vasvang in die Kategismus as konfessie. Die Skrifgronde hiervoor is Hebreërs 11:1, 3 sowel as Jakobus 2:19. Albei hierdie Skrifdele dien as bewysgronde om die kennisaspek van geloof te begrond. Hierdie artikel dui aan hoe die Kategismus bogenoemde Skrifgronde verreken om geloof as voorwetenskaplike kennis te beskryf. Die kenniselement van geloof is die voorveronderstelling wat die eksegeet by die aanvang van sy wetenskaplike aktiwiteit op die tafel wil plaas. Hierdie voorwetenskaplike kennis dien ter ondersteuning van wetenskaplike teorievorming.

Faith and knowledge in the Heidelberg Catechism. The way in which the close relation between faith and knowledge should be understood, is still very prominent in current theological debates. This article studies the connection that is being described between faith and knowledge by question and answer 21 of the Heidelberg Catechism. In response to the scholasticism of the late Middle Ages with its particular emphasis on the knowledge element of faith, the time of the Reformation apparently brought a more balanced view on the relationship between faith and knowledge thanks to specifically Calvin who had a certain influence on the formulation of faith's knowledge component. This gave to Ursinus and the rest of the commission responsible the breeding ground to capture this unique relationship into the Catechism as confession. Scriptural grounds for this relationship are found in Hebrews 11:1, 3 and James 2:19. Both these passages serve as basis for the knowledge aspect of faith. This article shows how the Catechism discounts these Scriptural passages to describe faith as a pre-scientific element in the scientific process. The knowledge-element of faith is the presupposition which the exegete wants to place on the table. This pre-scientific knowledge serves as support for the formulation of scientific theories.

\section{Inleiding}

Van Huyssteen (1986:99) formuleer die vraag: 'Hoe verantwoord [mens] die rol van die teoloog se eie persoonlike geloofsverbintenis ten opsigte van uiteindelike teorievorming in teologie?' Hierdie vraag plaas onmiddellik die rol van voorveronderstellings tydens wetenskapsbeoefening onder die soeklig. Die gereformeerde hoofstroom van teologie, en die wyse waarop teologie hierbinne beoefen word, word in baie opsigte beskou as ' $n$ tipe verdedigingsmeganisme teen die verandering wat die postmodernisme vir teologie as wetenskap inhou (Van Huyssteen 1986:38). Wanneer teoloë agter 'n geloofstandpunt skuil wat, volgens hulle, ononderhandelbaar is, of wanneer sogenaamde nuwe kennis of moderne insigte teoloë se behoudende geloofstandpunte bevraagteken, word die eeue-oue spanning tussen geloof en kennis telkens weer op die spits gedryf (Van der Walt 2004:3-4). Deur die eeue heen is dit immers duidelik dat geloof die Skrifbeskouing van gelowiges en gelowige wetenskaplikes raak: geloof is onderliggend aan gelowiges se begrip van die Bybel, ook binne 'n postmoderne tyd; geloof raak die hermeneutiese uitgangspunte in die verstaan van die Bybel sowel as die skeppingswerklikheid. Wanneer die geloofsvertrekpunt van 'n Skrifverklaarder onder die soeklig kom, ontstaan die vraag na die strekwydte van die invloed daarvan op die insameling en sistematisering van kennis.

By die herdenking van die 450-jarige bestaan van die Heidelbergse Kategismus (HK), word die genoemde vraagstuk in hierdie artikel aan die orde gebring deur die bestudering van Sondag 7 (vraag en antwoord 21) van die HK. 
Sondag 7, vraag en antwoord 21, van die HK lui:

Vraag: Wat is ' $n$ ware geloof?

Antwoord: 'n Ware geloof is nie alleen ' $n$ vasstaande kennis waardeur ek alles wat God in sy Woord aan ons geopenbaar het, vir waar aanvaar nie, maar ook 'n vaste vertroue, wat die Heilige Gees deur die evangelie in my hart wek, naamlik dat God nie net aan ander nie, maar ook aan my uit loutere genade slegs op grond van die verdienste van Christus vergewing van sondes, ewige geregtigheid en saligheid, geskenk het.

Met hierdie woorde word geloof direk aan kennis verbind. Volgens die HK is geloof in die eerste plek 'n vasstaande kennis dat dít wat in die Bybel staan, die waarheid is. Daarmee saam ook die stelling dat geloof ' $n$ vaste vertroue is dat genoemde kennis ' $n$ realiteit in die gelowige se lewe sal word.

Met Van Huyssteen (1986) se vraag aan die begin as katalisator, word die geloofsraamwerk wat deur vraag en antwoord 21 van die HK gestel word, verder ondersoek. Die aktualiteit van so 'n ondersoek berus daarin dat geloof as voorwetenskaplike wete (of voorwetenskaplike kennis) omvattend is ten opsigte van die Skrifverklaarder se benadering tot die Bybel en bepaal sy of haar interpretasie daarvan (Van der Walt 2004:3).

'n Bespreking rondom die mate waartoe geloof as voorwetenskaplike kennis 'n rol speel tydens Skrifverklaring, is nie nuut in die teologiese wetenskap nie. Van der Walt (2004) het alreeds die gedagtelyne hieroor saamgevat, veral met betrekking tot die Suid-Afrikaanse teologiese denkwêreld. Soos reeds hierbo genoem, word 'n geloofsuitgangspunt binne die wetenskaplike arena dikwels as 'n naïewe benadering tot wetenskapsbeoefening beskou. Aan die ander kant lei kennisoorspanning in wetenskapsbeoefening tot die persepsie dat eietydse kennis die sleutel is om die Bybel binne die postmodernisme te 'her-verstaan' en te 'ken'.

Hierdie artikel ondersoek nie die bogenoemde bespreking nie, maar wil vanuit die HK lig op die verband tussen geloof en kennis werp, veral met betrekking tot hedendaagse teologiese debatte wat in die lig staan van 'n skynbare kennisoorspanning en geloofsverskraling binne 'n postmoderne tydperk.

Die belydenisskrifte wat vir die gelowige ' $n$ samevatting van geloofstandpunte is, gee uiting aan die voorwetenskaplike kennis van die Skrifverklaarder. Wanneer die HK in Sondag 7 , spesifiek vraag en antwoord 21, die vraagstuk oor geloof aan die orde bring, word die noue verband tussen geloof en kennis gestel. Aangesien hierdie bestaande band enersyds 'n omskrywing van die essensie van geloof gee, bied dit aan die ander kant ook 'n klaarblyklike begrensing van (wetenskaplike) kennis.

Die belydenisskrifte, waaronder die HK, staan nie los van die Skrif nie. Belydenisskrifte poog om in die eerste instansie 'n 'naspreek' van die Bybel te wees (Du Plooy 1993:8). Die hoogste gesag, die norma normans [bindende reël], is slegs die Skrif. Die konfessie is altyd die norma normata [afgeleide reël] (Pont 1983:10; Spoelstra 1989:301; Van Wyk 1995:253). As vorm van uiting van geloof (regula fidei) (vgl. Coertzen 1991:142), dien die konfessie as 'n raamwerk waarbinne aspekte van die Bybel verstaan word (Van der Walt 2001:23). Die konfessie spreek dus oor die aard van die verband tussen geloof en dit wat geglo word.

Dit is algemene kennis dat die belydenisskrifte teen die agtergrond van spesifieke historiese kontekste ontstaan het (Spangenberg 1995:200). Belydenisskrifte vertoon die spore van die tyd en die konteks waarin dit opgestel is (Van Niekerk 1987:14). Dit is moontlik dat die bestudering van hierdie kontekste waardevolle insig kan bied in die faktore wat aanleiding tot formulering en sistematiese samevatting van Skrifuitsprake gegee het, en meer spesifiek waar hierdie sistematisering in die HK relevansie het met betrekking tot geloof in verband met kennis.

\section{Die Middeleeuse Skolastiek Die Skolastiek en die Reformasie}

Dit is nie ' $n$ onbekende feit dat die hervormers laer getrek het teen die opvattings van die Skolastiek van die dertiende tot die vyftiende eeu nie (Platt 1982:4) en dat die Skolastiek grootliks die denkklimaat was waarbinne die HK opgestel is (Gaybba 1998:41-42). Die skolastiese denke van hierdie tydperk het die beskouinge oor geloof tot ' $n$ blote intellektuele oefening gereduseer (Smit 1998:283-284) en het onderskeid getref tussen geloof as 'n vorm van kennis, geloof as 'n blote weg na die waarheid en geloof as 'n spirituele oefening (Berkhoff 2009:212). Luther het die rol wat die intellek in die teologie speel, skerp afgewys (Brown 1990:148), terwyl Calvyn (1988) in sy Institusie (3.2.2) die skolastiese redusering van geloof tot ' $n$ verstandelike vermoë van die mens veroordeel.

Ten opsigte van geloof het die Skolastiek klem op die fides implicita [inherente geloof] gelê en voorts onderskeid tussen die fides informis [dooie geloof] en fides formata [volwasse geloof] getref. Die fides implicita het die intellektuele geloofsvermoëns wat by elke mens teenwoordig is, beklemtoon en die gepaardgaande onderskeiding tussen fides informis en fides formata het met 'n grondliggende verintellektualisering van die geloof te make gehad. Kortweg behels die onderskeid tussen laasgenoemde twee terme die skolastiese beskouing van die verskil tussen 'n eerste, amper naïewe stadium van geloof en die latere volwasse geloof wat deur liefdesdade tot volle ontplooiing kom (Van Niekerk 1991:33).

Tydens die Konsilie van Trente (1545-1563) het die Roomse Kerk sy eie posisie verskans en die kern van die hervormers se standpunt verwerp. Die Roomse Kerk het geleer dat die Bybel die onfeilbare Woord van God is, maar dat die ongeskrewe kerklike tradisies van die kerk gelyk is daarmee. Die Skrifuitleg oor geloofsake moet ooreenstem met die kerklike leer (Helberg 1983:17).

In 'n sekere sin het reaksie op die uitsprake van die genoemde konsilie 'n periode van sogenaamde Protestantse 
Skolastisisme ingelui (vgl. Schulze 1978:232-233). Alhoewel hierdie tydperk in sommige kringe as konfessionele verstarring beskou is, was dit ook ' $n$ tydperk waarin die breë lyne van die Reformasie en die gepaardgaandebewuswording van die strieming van die Roomse Kerk nie ligtelik opgevat is nie. Binne hierdie lyne het die suiwerheid van die leer neerslag gevind in die klassieke dogmatiese sisteme wat op die fondament wat die Reformasie gelê het, gebou was. 'n Belangrike nalatenskap van die post-reformatoriese skolastiek was onder andere 'n rykdom van sistematiese uiteensettinge van die leer en ' $n$ indringende analise van die verhouding tussen rede (verstand) en openbaring (Schulze ibid:233). Gaybba (1998:43-44) erken byvoorbeeld die rol wat Aristoteliaanse logika sowel as 'n hele paar Aristoteliaanse filosofiese konsepte gespeel het in die verdediging en sistematisering van die reformatoriese uitgangspunte in die polemiek teen suiwer skolastiese standpunte.

\section{Die Reformasie as ruimte vir konfessievorming}

Gedurende die Reformasie is hernieude klem op die sentraliteit en belangrikheid van die Bybel as Woord van God gelê. Die rede en intellek van die mens is met suspisie bejeën, hoofsaaklik as gevolg van die skolastiese denke van die laat-Middeleeue. Luther het die gebruik van die menslike rede in die beoefening van teologie totaal verwerp (Gaybba 1998:43). Tog het sy student, Melanchthon, en ook Calvyn, 'n groter ontvanklikheid daarvoor laat blyk (Gaybba ibid:42-43), dog met sekere voorbehoude. Calvyn (1853:326) het geloof en kennis dikwels as sinonieme hanteer. Deur 'n meer intensiewe bestudering van sy Institusie, word dit egter duidelik dat daar ' $n$ bepaalde orde by Calvyn te bespeur is aangaande die verhouding geloof tot kennis, en dat hierdie orde die lyn vorm wat in artikel 22 van die Nederlandse Geloofsbelydenis (NGB) gevolg word.

Vir Calvyn was geloof ongetwyfeld kennis (Van Genderen 1982:7), maar kennis wat op geloof volg. Geloof gaan kennis dus vooraf, maar op so 'n wyse dat geloof en kennis nie van mekaar geskei kan word nie. Geloof is nodig om tot ware kennis van God te kom. Calvyn het hierdie orde alreeds etlike jare voor sy Institusie verkondig toe hy in sy Geneefse Kategismus (vraag en antwoord 15; vgl. Calvyn 1981:7) geloof as die kern van kennis van God bestempel het. Calvyn het voorkeur gegee aan die term cognitio as sleutelbegrip waaromheen hy sy omskrywing van geloof gebou het, omdat dit vir hom om die sekerheid as wesenseienskap van die geloof gegaan het (Van Niekerk 1991:9).

Calvyn (1988) het breedvoerig (amper filosofies) soos volg oor die sekerheid as wesenseienskap van geloof uitgebrei:

Wanneer ons die geloof kennis noem, verstaan ons nie daaronder sintuiglike waarneming in die sin waarin ' $n$ mens gewoonlik dinge waarneem nie. Want dit is soveel verhewener dat die mens se verstand homself moet oortref en oorwin om dit te bereik. Want selfs wanneer die mens se verstand dit wel bereik, begryp hy nog nie wat hy waarneem nie. Wanneer hy egter oortuig is van iets wat hy nog nie begryp nie, begryp hy juis deur die sekerheid van sy oortuiging meer as wanneer hy met sy begripsvermoë iets mensliks sou kon deurgrond. (Inst. 3.2.14)
Calvyn het dus duidelik onderskeid gemaak tussen die begripsvermoë van die mens se natuurlike kennis, en die kennis wat deur die geloof verkry word. Die natuurlike begripsvermoë skiet tekort wanneer dit by kennis van God kom. Geloofskennis rig die mens in sy ganse wese op die bonatuurlike dinge, die onsienlike wat deur die geloof sienbaar en kenbaar word (Graafland 1961:15; Thomas 1961:58-60). Sodoende word sekerheid verkry wat andersins nie moontlik sou wees nie.

Geloof en sekerheid was vir Calvyn twee kante van dieselfde munt. Geloof impliseer per definisie sekerheid. Omgekeerd is daar ook geen sekerheid sonder geloof nie. Om te glo beteken om seker te wees van wat geglo word. Met verwysing na hierdie 'filosofie' van Calvyn merk Theron (1984:85) op: 'Die geloof steun nie op homself nie, maar op God, want op sigself is die geloof leeg. Maar juis daarom behoort sekerheid tot die wese van die geloof.'

Vir Calvyn was die sekerheid van geloofskennis gebou en terselfdertyd gerig op die beloftes wat God in die evangelie gee. In hierdie verband verduidelik Van Niekerk (1991:11) dat geloof as aktiewe wilsdaad van die mens vir Calvyn nie op sigself so vas en seker was nie. Die cognitio van die geloof is seker omdat dit op die Woord van God se waaragtige en vaste belofte gerig is (Graafland 1973:92), want, skryf Calvyn (1988):

die aard van geloof kan klaarblyklik nie beter of duideliker verklaar word as uit die wese van God se belofte nie. Daarop steun die geloof soos op 'n eie fondament, sodat dit onmiddellik in duie stort of eerder verdwyn sodra die wese van sy belofte weggeneem word. (Inst. 3.2.41)

Daarom kan geloof, ongeag die kwaliteit of enigiets anders daarvan, nie die mens red nie, maar God alleen wat sy heilsvoorneme jeens die mens daadwerklik in Christus bekendgemaak én uitgevoer het. Die sekerheid van die geloof hang dus ten volle saam met die aard van die heil. Met ander woorde, dit wat deur die geloof geken word, het hierdie heil as inhoud (Van Niekerk 1991:12). Calvyn (1988) beklemtoon die gerigtheid van die geloof op die Woord van die waarheid as hy skryf dat 'die geloof vir ewig in 'n verhouding met die Woord staan en dat dit net so min van die Woord losgeskeur kan word as wat die strale van die son, wat die bron daarvan is, losgemaak kan word' (Inst. 3.2.5).

\section{Geloof as kennis in Sondag 7}

Moontlik as gevolg van die invloed van die Skolastiek, het die Protestantse skolastiek ook mank gegaan aan die geloofsraamwerk waarbinne kennis figureer. Die formulering van 'n 'definisie' van ware geloof in Sondag 7 van die HK word onder andere toegedig aan Calvyn se poging om geloof los te maak van die intellektuele skemas van die Skolastiek sonder om geloof en kennis geheel van mekaar te vervreem (Van Niekerk 1991). Dit is egter nodig om die begronding van vraag en antwoord 21 in die Skrif te kontroleer ten einde te begryp hoe die HK met behulp van die Skrif die verband tussen geloof en kennis verwoord. 


\section{Skrifbewyse van die HK}

Wanneer die HK in Sondag 7 die vraag oor die wese van ware geloof aan die orde stel, staan twee tekste in die eerste Duitse uitgawe van 1563 voorop, naamlik Hebreërs 11 en Jakobus 2 (Oberholzer 1986:43). Dit was eers in 1584 dat Ursinus 'n weergawe van die Kategismus uitgegee het (gebaseer op die vierde Duitse uitgawe van die HK soos uitgevaardig deur Frederik III op 15 November 1563) waarin hy die teksverwysings uitgebrei het sodat spesifieke verse daarby ingesluit is. Hiervolgens word Hebreërs 11:3 en Jakobus 2:19 as teksverwysings by vraag en antwoord 21 gebruik.

\section{Hebreërs 11:1, 3}

By die HK se 'definiëring' van geloof as vaste vertroue, is die eerste Skrifberoep wat deur die opstellers van die Kategismus aangevoer word Hebreërs 11:1 en 3. Eksegese van hierdie verse bring aan die lig dat kennis (van God se ewige krag en Godheid) alleen deur die geloof bereikbaar word. Na analogie van die bewoording in Hebreërs 11:3 kan daar sonder die geloof nie geweet of ingesien word dat die wêreld deur God tot stand gekom het, of dat God vandag steeds oor alle dinge heers en regeer nie.

In Ursinus (1886:143) se verklaring van vraag en antwoord 21 van die HK blyk die betekenis van Hebreërs 11:1 en 3 duidelik wanneer hy geloof beskryf as 'n sekere kennis van dit wat deur die mens as waar beskou word op grond van getuienis (van God) waaraan nie getwyfel word nie; met ander woorde dit is 'n sekere kennis van alles wat deur God in die Skrif aangaande Homself, sy wil, sy werke en sy genade geopenbaar word.

'n Deegliker studie van Hebreërs 11:1 en 3 wat van die mees prominente bewysgronde is, is noodsaaklik in die besinning oor geloof en kennis in vraag en antwoord 21 en bring die volgende aan die lig: Die karakterisering van geloof in Hebreërs 11:1 vertak in twee komplemente,

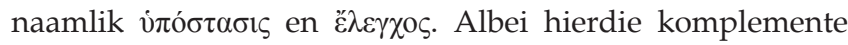
het betrekking op $\pi \rho \alpha \gamma \mu \alpha ́ \tau \omega v$, wat op sy beurt weer inhoud aan die komplemente gee. Die genitief $\pi \rho \alpha \gamma \mu \alpha \dot{\tau} \omega \nu$ word weer inhoudelik gekwalifiseer deur twee genitiewe deelwoorde,

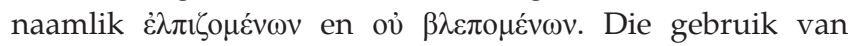
die negativeringspartikel oủ saam met die partisipium $\beta \lambda \varepsilon \pi$ o $\mu \varepsilon v \omega v$ is vreemd aan Nuwe-Testamentiese Grieks. Volgens Lane (1991:326) moet die teenwoordigheid van oủ saam met $\beta \lambda \varepsilon \pi$ o $\varepsilon^{\prime} v \omega v$ beteken dat die negativering deurslaggewend is. Dit beklemtoon die feit dat gebeure of dinge nie deur objektiewe waarneming gesien kan word

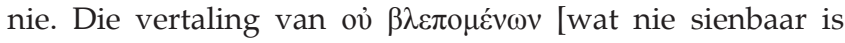
nie] dat dit $\mu \eta \delta \varepsilon \dot{\pi} \omega \beta \lambda \varepsilon \pi$ o $\varepsilon \dot{v} \omega v$ [nog nie gesien nie] moes lees, word geregverdig deur die korresponderende vorm in Hebreërs 11:7.

Die sintaksis van Hebreërs 11:3 beklemtoon die aanvangswoord $\pi$ í $\sigma \varepsilon 1$. Die datief $\pi$ í $\sigma \varepsilon 1$ word as datief van oorsaak verklaar en dui daarom op die deurslaggewende geaardheid van geloof. Nie net word daar vanuit die geloof gelewe nie (Heb 10:38, 39), maar ook geweet of geken. Om hierdie rede verkry vooũ $\mu \varepsilon v$ ook besondere betekenis naas $\pi i ́ \sigma \tau \varepsilon$.

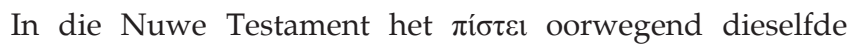
betekenis as in klassieke Griekse literatuur, naamlik getrouheid en vertroue of geloof (Ursinus 1956:111), alhoewel eersgenoemde baie selde gebruik word. Die betekenis vertroue of geloof word uitsluitlik in 'n religieuse sin gebruik en verstaan (Bultmann 1968:204). Volgens Bultmann (ibid:205) was $\pi i ́ \sigma \tau \varepsilon \iota$ reeds in die vroegste Christelike tradisie die vernaamste term om die verhouding van die mens met God te beskryf danksy die nalatenskap van die OuTestamentiese en Joodse gebruik daarvan. Michel (1975:599) merk in hierdie verband op dat die gereelde gebruik van die werkwoordvorm $(\pi \imath \sigma \tau \varepsilon v \omega \omega)$ in Nuwe-Testamentiese Grieks in

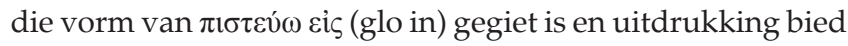
aan die aanvaarding van die evangelieboodskap van Jesus Christus. Hierdie is 'n belangrike ontwikkeling vanaf $\pi \iota \tau \tau \varepsilon v \omega$ ö $\tau$ [glo dat] in die LXX en die vroegste Christelike tradisies wat na 'n spesifieke moment in die geskiedenis van Jesus verwys (vgl. Rom 10:9; 1 Tess 4:14).

Die gehoorsaamheidsaspek is inherent deel van die begrip geloof in die Nuwe Testament (Käsemann 1984:38).

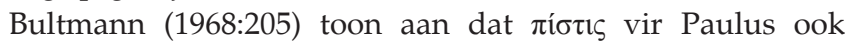
ù $\pi \alpha$ коń [gehoorsaamheid] beteken wanneer Romeine 1:8 en 1 Tessalonisense 1:8 vergelyk word met Romeine 15:18; 16:18, of 2 Korintiërs 10:5 met 2 Korintiërs 10:15. Deur te weier om te glo, is om ongehoorsaam te wees aan die geregtigheid wat deur die evangelie verkondig word (vgl. Rom 10:16). Daarom noem Paulus die gelowige belydenis van die evangelie die

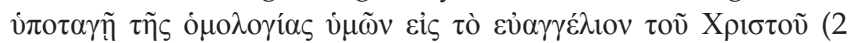
Kor 9:13) en verbind hy die twee begrippe met mekaar in Romeine 1:5.

In die Nuwe Testament behels geloof ook vertroue en hoop. Veral in die evangelies dra geloof die betekenis van vertroue in Jesus se krag en vermoë om siekes te genees, sondes te vergewe en duiwels uit te dryf (Michel 1975:599-600). In Romeine 4:18 word geloof en hoop met mekaar verbind en uit die beskrywing van geloof in Hebreërs 11:1 blyk dit duidelik dat geloof in God se beloftes hoop inhou (vgl. Calvyn 1988, Inst. 3.2.42). Om hierdie rede kan gelowiges uit die $\mathrm{Ou}$ Testament as voorbeelde dien van hoe geloof op die toekoms gerig kan word en hoe geloof hoop is op dit wat nog moet realiseer (vgl. Heb 11:4vv) - in so'n mate dat die beloftes deur geloof alreeds 'n werklikheid is (Guthrie 1981:596). Alhoewel die verband tussen geloof en hoop verskeie variasies toon, word die verhouding kernagtig in 1 Petrus 1:21 saamgevat: '... julle wat deur Hom glo in God wat Hom uit die dode opgewek en Hom heerlikheid gegee het, sodat julle geloof en hoop op God kan wees' (1933/1953-vertaling).

Louw \& Nida (1988 I:376) se komponensiële woordanalise volgens semantiese domeine bepaal dat $\pi$ í $\tau \iota \varsigma$ in Hebreërs 11:1-3 die volgende betekenis het: Geloof, tot die mate van algehele vertroue en oorgawe. Deur kontrastering met naasliggende betekenisvelde, is geloof in Hebreërs 11:1-3, volgens Louw \& Nida (1988,I:376-378), meer as net blote 
vertroue of bloot iets wat aanleiding gee tot verdere vertroue.

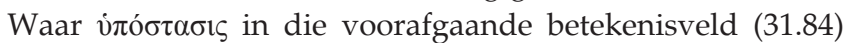
aanleiding tot vertroue en oortuiging gee (Louw \& Nida ibid $\mathrm{I}: 376)$, is geloof daarenteen algehele vertroue en oortuiging.

Die omskrywing hierbo sluit aan by Calvyn (1988, Inst. 3.2.41) se begrip van geloof in Hebreërs 11:1 waar hy noem dat geloof op die beloftes van God steun. Uiteraard is geloof, aldus Calvyn, op die beloofde saligheid gerig wat vir die menslike oog nie sigbaar is nie. Die geheimenisse aangaande die beloftes van God oor die mens se saligheid kan nie op sigself en na eie aard waargeneem word nie. Calvyn sê dat die beloftes van God slegs in die Woord van God gesien kan word. Daarom behoort daar só 'n vaste oortuiging by die mens te wees rakende die waarheid van die Woord, naamlik dat alles wat in die Woord gesê word, as die werklike vervulling daarvan beskou moet word. Om te glo, volgens Calvyn, is om in algehele vertroue en oortuiging vooruit te weet (vgl. ook Graber 1943:7-8). Brawley (1993:95) beskryf hierdie vooruit weet in terme van die sekerheid van 'n apokaliptiese oorwinning deur Christus en sy wederkoms (vgl. ook Dörrie 1955:202). Swetnam (1974:339) meen dat geloof 'n objektiewe

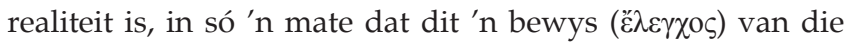
onsienbare genoem word.

In Hebreërs 11:3 word voćw, soos in die Nuwe Testament, oor die algemeen vir die betekenis van die sinsnedes om te begryp, om te herken en om te verstaan gebruik. Dit word ook oorwegend in religieuse sin gebruik met verwysing na God, sy handelinge en sy wil (Harder 1978:128). Die aanhaling van Jesaja 6:10 in Johannes 12:40 dui daarop dat voćw ook soms as 'n funksie van die hart verstaan word, en as sodanig 'n spirituele herkenning of verstaan behels. Die onsigbare van God se handelinge en wil word op 'n spirituele wyse begryp of ingesien. Die onsienlike word deurdink en oordink deur 'n proses waarvan die refleksie vanaf die skepping na die Skepper heen lei (vgl. Rom 1:20). God se skeppingsorde en sy voorsienigheid deur die geskiedenis weerspieël sy ewigheid en almag. Die onsigbare God word daarom, volgens Behm (1967:950), by die oordenking van sy werke (finitum capax infiniti) gesien. Op hierdie wyse word die gedagte van die mens op die Outeur van hemel en aarde gerig. Kennis van die ewige en onsienbare God word deur die sienbare skeppingsorde verkry.

Harder (1978:128) merk op dat geloof 'n voorvereiste is om die skepping te verstaan as die werk van God. Daarom is daar volgens Behm (1967:951) 'n verband tussen Romeine 1:20 en Hebreërs 11:3, alhoewel hy meen dat laasgenoemde vers die gedagte van weet of ken verder voer as Romeine 1:20 vanweë die geloofsaspek wat daarin na vore kom. Die realiteit van die onsienlike wat in Hebreërs 11:3 omskryf word as die waarheid van die oorsprong van die wêreld deur God se skeppingswoord, is nie vir die sintuiglike of rasionele van die mens toeganklik nie, maar slegs vir die kennis van die mens in soverre daardie kennis in geloof gegrond is. Geloof is, volgens Hebreërs 11:3, die medium waardeur kennis geskied (Grässer 1965:129). Om te verstaan dat God se wil die basis van alle dinge vorm, is om in terme van geloof te dink. Hierdie wete het geloof as voorveronderstelling en is daarom die innerlike oortuiging dat die onsigbare dinge werklikheid is (vgl. Clark 1996:40). Vir die skrywer van Hebreërs is hierdie werklikheid ook die werklikheid van die verlossing van die mens. Vir hom is kennis van God in geloof in die Godsopenbaring gegrond (Behm 1967:951).

Calvyn (1984, Inst. 1.5.14), met verwysing na Hebreërs 11:3, skryf dat hoewel God se skepping die mens van alle kante af soos ligte bestraal, dit deur die menslike verstand uitgedoof word nog voordat dit 'n voller glans kan afgee.

Calvyn gebruik dikwels geloof en kennis in dieselfde asem. In sy kommentaar op Daniël 11:32 merk hy op dat hierdie genoemde kennis nie die betekenis van 'n kille verbeelding dra nie, maar dat dit as geloof verstaan moet word (Calvyn 1853:326). Na aanleiding van Handelinge 16:31 noem Calvyn (1970:193) dat geloof 'n betroubare en onderskeidende kennis van Christus is, terwyl hy (Calvyn 1971:717-719) in sy verklaring van Johannes 17:3 kennis en geloof as sinonieme gebruik.

Oormatige klem op die kennisaspek van geloof laat dit egter kil en gevoelloos; dit stel geloof altyd bloot aan diskussie, maar nie aan belydenis nie; dit maak geloof beginselvas, maar sonder liefde. Aan die ander kant is die kennisaspek van geloof onontbeerlik. Geloof is nie alleen maar 'n gevoelsaak sonder die dogma nie. Vir die teologie bied geloofoorspanning en kennisonderspanning net soveel slaggate as kennisoorspanning en geloofonderspanning (Veldkamp s.a.:92-93; Van Dijk 1980:46).

Die volgorde van 'kennis' en 'vertroue' in Sondag 7 van die Kategismus moet egter nie as prioriteitsvolgorde vertolk word nie. Dit blyk juis uit die ontstaanskonteks van die Kategismus. Omdat die HK opgestel is in 'n tyd waarin die Skolastiek 'n oordrewe klem op kennis geplaas het, is dit begryplik dat die opstellers van die $\mathrm{HK}$, binne die ruimte wat deur die Reformasie daarvoor geskep is, in die eerste plek die kennis en/of wete-aspek van geloof binne gebalanseerde perspektief wou stel. Daarom: '[N]ie alleen 'n vasstaande kennis $[\ldots$ nie], maar ook 'n vaste vertroue $[\ldots]$ '. Origens word 'kennis' in Sondag 7 van die HK gekwalifiseer as '[...] waardeur ek alles wat God in sy Woord aan ons geopenbaar het, vir waar aanvaar [...]'. Die HK bied dus die raamwerk vir breë openbaringshistoriese lyne vir die verstaan van Hebreërs 10:38-11:3 ten opsigte van geloof en kennis. Hieroor is Ursinus (1886:143-144) duidelik in sy eie verklaring van Sondag 7 (vraag en antwoord 21) van die HK wanneer hy daarop wys dat geloof waarvan in die Heilige Skrif melding gemaak word, kennis van God behels; God se wil, werke en genade, met ander woorde die geheel van God se Woord wat Hy aan die kerk gegee het (outeur se eie kursivisering).

\section{Jakobus 2:19}

Die tweede prominente bewysteks word as Jakobus 2:19 aangedui waar geskryf staan: 'Glo jy dat daar net een God is? Dit is reg. Die bose geeste glo dit ook - en hulle sidder van angs (1983-vertaling). 
Op die oog af hou hierdie teks uit Jakobus 2 nie veel verband met die stelling dat geloof ook kennis is nie. Daar moet egter in gedagte gehou word dat 'om te glo' in die vroegChristelike tradisie nog nie die betekenis van saligmakende geloof gedra het nie (Grosheide 1935:40). Hiermee saam moet in gedagte gehou word dat die brief van Jakobus een van die vroegste Christelike geskrifte is wat in die Nuwe Testament opgeneem is (vgl. Coetzee 1981:23; De Villiers 1988:128). Die ontwikkeling van die begrip om te glo het wel teen hierdie tyd al 'n religieuse konnotasie gehad, maar het nog nie so ver gestrek as om 'saligmakende geloof' te veronderstel nie. Volgens Michel (1975:599) weerspieël die

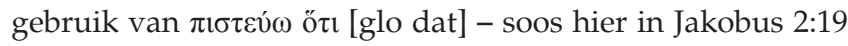

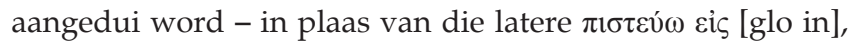
'n vroeë vorm van geloofstellings in die Christelike tradisie en dra dit hoofsaaklik die betekenis van vertroue in of kennis van die waarheid. Die begrippe geloof en glo, soos wat dit in die vroeëre Nuwe-Testamentiese geskrifte voorkom, het dus steeds in 'n groot mate karaktertrekke van die OuTestamentiese en later Joodse verstaan daarvan getoon.

As ontwikkeling vanuit die Ou Testament en die Jodedom, het die betekenis van 'om te glo' in die vroeëre Christelike tradisies ingehou dat die waarheid aangaande 'n saak erken word (vgl. Bultmann 1968:205). Dit kon ook na die waarheid aangaande persone (bv. Moses in Num 12:7), aangaande 'n voorwerp (vgl. Jes 22:23), na woorde wat as die waarheid beskou is (vgl. Gen 42:20) of aangaande God (vgl. Weiser

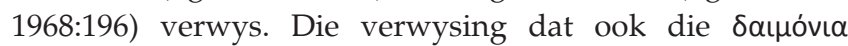
$\pi \imath \sigma \tau \varepsilon v 0 v \sigma \iota v$, versterk die gedagte dat geloof hier in die sin van kennis van die waarheid verstaan moet word.

Dit kom egter voor asof die konteks waarin Jakobus 2:19 staan tog die teendeel wil stel, naamlik dat dit in hierdie perikoop om meer as net kennis gaan; dat dit wel oor saligmakende geloof handel en nie net oor geloof as kennis nie. Aan die begin van die perikoop lyk dit asof Jakobus 2:14 'n inleiding tot 'n bespreking van die saligmakende geloof bied. Uit Jakobus 2:21 kan ook weer afgelei word dat geloof met vryspraak deur God in verband gebring moet word (vgl. ook vers 23, 25). Die beredenering in hierdie perikoop moet egter in sy geheel gesien word. Dit is waar dat Jakobus hier handel oor geloof wat 'n mens tot die saligheid lei, maar die aard van hierdie geloof is waaroor hy uitwei. Geloof wat tot saligheid lei, is nie 'n geloof wat vassteek by teorie nie, maar 'n geloof wat oorgaan tot die praktyk. Daarom is die punt wat Jakobus in vers 19 maak: Geloof is nie net kennis van God nie (Luther se standpunt; vgl. Kral 1961:28; vgl. ook Exalto s.a.:83; De Graaf 1954:135). Die duiwel glo (weet) ook, en hy sidder van angs. Geloof is kennis, dit raak duidelik, maar geloof moet ook oorgaan tot 'n liefdeshandeling teenoor jou naaste. Jakobus 2:19 behandel dus geloof as gelykstaande aan kennis. Alhoewel geloof alleen in die sin van blote kennis nie genoegsaam is om tot saligheid te lei nie, blyk dit duidelik dat geloof en kennis in vers 19 in verband met mekaar gebring word. Ursinus (1886:144) onderstreep hierdie beredenering in die verklaring van vraag en antwoord 21 (Sondag 7 van die HK) wanneer hy die voorkoms van 'historiese geloof met verwysing na Jakobus 2:19 beskryf. Volgens Ursinus glo die duiwels dat God 'n enige wese is, soos Hy Homself openbaar het. Die duiwels glo ook dat God se openbaring seker en vas is, maar hulle geloof is bloot ' $n$ verstandelike oortuiging aangaande God en sy werke.

In sy verklaring van vraag en antwoord 21 is Ursinus (1886:147) duidelik daaroor dat die werklike saligmakende geloof nie alleen hierdie verstandelike oortuiging is nie, maar ook die vertroue dat die God van kennis 'n persoonlike God van nabyheid is. Die vertroue wat in vraag en antwoord 21 as onderdeel van geloof beskryf word, is in so 'n mate aan kennis verbind dat die openbaringshistoriese lyne wat deur die kenniselement bevat word, die mens tot vertroue opwek dat dit wat hy of sy weet (kennis) ook vir hom of haar bedoel en van waarde is (vertroue). Die spore van Jakobus 2:19 (en uiteraard ook Heb 11:1, 3) is dus hier duidelik merkbaar wanneer Ursinus geloof en kennis in 'n noue verband met mekaar beskryf.

\section{Voorkritiese Skrifuitleg en konfessievorming}

Die Reformasie dien as agtergrond waarteen die drie formuliere van eenheid geformuleer is. Runia (1984:122) wys daarop dat die Skrifgebruik in die tyd van die Reformasie nie in isolasie geskied het nie en beter verstaan kan word as dit met die voorafgaande tydperke in die geskiedenis van Skrifinterpretasie in verband gebring word. In hierdie opsig vind die Skrifgebruik gedurende die Reformasie veral by die teologiese interpretasie van die Kerkvaders aansluiting met die klem op die letterlike betekenis van die teks soos by die Joodse eksegete gedurende die Middeleeue en die belangstelling in die grondtale van die Humaniste (vgl. Stuhlmacher 1979:86-87). Calvyn is byvoorbeeld veral bekend vir sy beklemtoning van die grammatieshistoriese lees van die Skrif (Bosman 1987:40). Luther het weer beklemtoon dat daar by die eenvoudige en natuurlike betekenis van die woorde gebly moes word (Van Rooy 1991:30). In die geheel gesien het die hervormers teruggekeer na die eenvoudige, letterlike betekenis van die Skrif (Helberg 1983:15) en dit is teen hierdie agtergrond van Skrifverstaan en -uitleg dat geloofstandpunte neerslag in die konfessies van die tyd gevind het.

Bosman (1987:43) tipeer Skrifuitleg voor die Verligting in die agtiende eeu as voorkrities, aangesien dit konsekwent deur die eksegeet se geloofsreëls (regula fidei) bepaal en begrens is. Met voorkritiese Skrifuitleg bedoel hy veral dat die eksegeet nie krities staan teen sy eie voorveronderstellings en die rol wat dit in sy interpretasie speel nie.

Van Rooy (1991:32) kritiseer hierdie siening. Hy meen dat dit tot 'n sekere mate anachronisties is. Hy stem toe dat die hantering van die Skrif voor die Verligting as voorkrities bestempel sou kon word, maar dat dit nog nie beteken dat die Skrifgebruik daarna in kritiese kringe deur ' $n$ erkenning van voorveronderstellings gekenmerk is nie. In die positivisme was daar'n poging om voorveronderstellingloos te werk deur 
sodanige voorveronderstellinglose interpretasies as objektief te beskou sonder dat die invloed van die positivistiese uitgangspunt op die interpretasie behoorlik raakgesien word.

Die verstaan van die rol wat voorveronderstellings tydens Skrifuitleg speel, het eers werklik gedurende die sestigerjare van die vorige eeu momentum begin kry met die verskyning van Thomas S. Kuhn se boek The structure of scientific revolutions waarin 'n oorspronklike alternatief vir die objektiewe karakter van positiwistiese wetenskapsbeoefening gebied word. Indien voorkritiese interpretasie getipeer word soos Bosman dit doen, kan kritiese interpretasie eers na die verskyning van Kuhn se werk moontlik wees.

Bosman (1987:44) oorweeg die moontlikheid dat Plato se invloed daartoe gelei het dat die Bybel in die vroeë Christendom as spieël van historiese gebeure en teologiese oortuigings beskou is. Die oortuiging dat teks en werklikheid in onmiddellike verband staan, het tot die siening gelei dat die teks van die Bybel aan die eksegeet direkte toegang tot die werklikheid waarbinne dit aanvanklik geformuleer is, verleen. Hierdie voorkritiese hantering van die Skrif kan egter nie sito-sito op die hervormers van toepassing gemaak word nie. Bosman (ibid:43) gee toe dat sy tipering 'n growwe veralgemening is. Die raamwerk waarbinne die hervormers geteologiseer het, was in 'n baie groot mate altyd 'n teenreaksie op denkstrome wat die eenheidskarakter van die Skrif bedreig het. Alhoewel die Reformasie aanvanklik die invloed wat die onaanvegbare posisie van die pous en die klerus op Skrifverstaan probeer teenwerk het, het die stryd ook uitgebrei om ander standpunte teen te werk. Hierdie magdom 'gevegsfronte' het die hervormers gehaas tot 'n voortdurende intellektuele besinning oor hoe die Bybel verstaan moet word (Van der Walt 2001:13).

Die feit dat menige van die hervormers standpunte, al dan nie, oor die kanonisiteit van die Bybelboeke gehad het, asook 'n bewustheid van teksvariasie wat by die hervormers aanwesig was (vgl. Bosman 1987:43), dui daarop dat die hervormers nie op 'n naïewe wyse met die teks omgegaan het nie. Die hervormers het wel die teks van die Bybel 'voorkrities' hanteer in dié opsig dat hulle 'n direkte verband tussen die teks en die werklikheid gesien het. Dat hierdie tekshantering aan die invloed van Plato toegeskryf moet word (Bosman ibid:44), is egter sterk te betwyfel. Die reformatore se Skrifhantering het immers bewustelik by die hermeneutiek van die Kerkvaders aangesluit, veral by die Antiocheense skool. Die Antiocheense skool se wyse van Skrifhantering het weer aangesluit, nie by die Griekse denkers nie, maar by die Joodse Rabbyne (vgl. Bruce 1979:2627). Teen hierdie agtergrond van Skrifuitleg en -hantering kom die HK in wording.

Die intensie van die HK was van die begin af duidelik. Frederik III se verduideliking in die voorrede tot die Kategismus se eerste uitgawe, lui soos volg (vertaald weergegee deur Oberholzer 1986):
Die jeug moet van die begin af in die eerste plek opgevoed word in die suiwere en ook eenvormige leer van die Heilige Evangelie en in die regskape kennis van God, en voortdurend daarin geoefen word. (bl. 17)

Verderaan skryf hy:

Daarmee sal die jeug voortaan in die kerke en skole Godsaliglik onderrig word en eenstemmig daartoe opgevoed word. Ook die predikers en skoolmeesters sal 'n seker en vaste vorm en maatstaf hê hoe hulle in die onderrig van die jeug moet optree ... (bl. 17)

Na sy oorsprong was die Kategismus dus 'n leerboek vir die kerk en jeug om van jongs af 'n eenvormige fondament te lê waarvan die kerk en samelewing die vrugte kon pluk (Bierma 2013:3-4). Frederik bekla juis in die voorrede oor die gebrek aan 'n eenvormige wyse van die jeug se onderrig met die gevolglike (nadelige) vrugte daarvan. Met die oogmerk van die welsyn van kerk en staat, moet kinders van vroeg af onderrig word in die vernaamste stukke van die Christelike leer, begelei word in die vrese van die Here en om kwaad te beteuel.

Dit blyk duidelik uit bogenoemde dat die primêre doel van die HK was om binne die kerk as instrument van onderrig te dien teenoor 'n dokument soos die NGB wat apologeties na buite gerig was (Van't Spijker 2009:254). Die latere waardering van die HK deur die kerke in Nederland as belydenisskrif en die gepaardgaande aanvaarding daarvan as belydenisskrif deur kerke wat nog later in die reformatoriese tradisie sou volg, staan op die spoor van hierdie aanvanklike bedoeling.

Bogenoemde bedoeling van die HK, naamlik dat daar geensins iets te sê was oor die rol van geloof vir die gelowige wetenskaplike nie, is egter nie waar nie. Calvyn (1988, Inst. 3.17.1) wys daarop dat daar by geloof nie sprake is van onkunde nie, maar van kennis; nie sprake van die mens wat in onwetendheid leef nie, maar met die wete van die heil wat in Christus gekom het. Geloof sonder kennis hang inhoudloos in die lug. Die omvang van die geloofskennis in die tydperk van die Reformasie, en soos dit neerslag in die HK gevind het, het 'n heilshistoriese fondasie. Vir Luther sowel as Calvyn is die ware teologie in die gekruisigde Jesus te vind (Van der Walt 2004:127). Teen hierdie agtergrond moet die aard van die kennis in vraag en antwoord 21 van die HK verstaan word as religieuse kennis van God. Die natuurlike begripsvermoë van die mens is nie genoegsaam om hierdie kennis aan te vul nie.

Vir die doeleindes om God en sy skepping in die regte perspektief te ken, om sy almag in die natuur te sien, om sy Woord as die waarheid te aanvaar, is geloof nodig. Veral Hebreërs 11:1-3 (as Skrifverwysing by vraag en antwoord 21), binne die konteks van die Hebreërboek se verkondiging van die wyse waarop God in die verlede gespreek het en in die hede steeds spreek deur sy Seun, kulmineer die spreke van God in Christus, dieenigste Middelaar en Hoëpriester. Hierdie aspek van God se openbaring word deur die Hebreërboek as die waarheid van God se verlossing voorgehou. Geloof en die kennis wat geloof aangaande God se verlossingshandelinge meebring, dien voorts as die raamwerk van die gelowige se 
lewe. Deur die geloof word gelewe, deur die geloof word gehoop, deur die geloof kom sekerheid, deur die geloof word geweet en geken. Die fokuspunt van geloof is kennis van dit wat God in die verlede gedoen het, huidig doen en in die toekoms gaan doen. Hierdie kennis is inderdaad religieuse kennis; kennis wat die gelowige in 'n posisie voor God stel waarin die mens sy kleinheid en afhanklikheid besef (Van der Walt 2004:128-129).

\section{Gevolgtrekking}

Indien die resultate van hierdie artikel saamgevat word, kom die volgende vanuit die $\mathrm{HK}$ en die begronding daarvan in die Skrif aan die lig ten opsigte van die verband tussen geloof en kennis:

In reaksie op die Skolastiek van die laat-Middeleeue met die klem op die verintellektualisering van geloof, het die Reformasie 'n klaarblyklike gebalanseerde nuansering van die verband tussen geloof en kennis tot gevolg gehad. Hiertoe het veral Calvyn 'n besondere bydrae gelewer en het hy 'n bepaalde invloed op die formulering van geloof se kenniselement gehad. Dit het ruimte gebied waarbinne Ursinus hierdie unieke verband in die Kategismus as konfessie kon vasvang.

Die bewystekste by vraag en antwoord 21 van die HK gebruik die woord geloof om die relasie van die mens tot God te beskryf. Hiervolgens is geloof ' $n$ uitwaartse handeling waarvolgens die mens in gehoorsaamheid sy totale hoop op God rig en algehele vertroue in God stel. Geloof steun op die beloftes van God, met ander woorde op dít wat nog nie vir die menslike oog sigbaar is nie. Geloof is in hierdie sin die daad van die mens waardeur dit wat God vir die toekoms beloof het, reeds in die hede verwerklik word.

Soos by geloof, word kennis ook in 'n religieuse sin verstaan en is dit op die ken van die onsienbare van God gerig. Die onsigbare dinge van God kan in sy sigbare werke gesien word. Kennis van die ewige en onsienbare God word deur die sienbare skeppingsorde verkry. Geloof dien as voorvereiste om hierdie skeppingswerklikheid as daad van God te verstaan. Die onsienbare werklikheid is slegs toeganklik vir die kennis van die mens indien, en slegs indien, die kennis van die mens in geloof gegrond is. Geloof dien as voorveronderstelling vir kennis van die onsienbare werklikheid van God.

Vraag en antwoord 21 van die HK se 'definiëring' van geloof as onder andere kennis, tipeer dit nie as wetenskaplike kennis nie. Die verstaan van die HK, tesame met die Skrifbegronding daarvan, toon aan hoedat geloof nie op sigself wetenskaplike kennis is nie. Die geloof, wat as gawe van God ontvang word, gee saam met die wetenskaplike proses vorming aan wetenskaplike kennis.

Die kenniselement van geloof is die voorveronderstelling wat die eksegeet by die aanvang van sy wetenskaplike aktiwiteit op die tafel wil plaas. Hierdie voorwetenskaplike kennis dien voorts ter ondersteuning van die proses van eksegese en van wetenskaplike teorievorming, alles gedaan binne die besef van die feilbaarheid van menslike vermoëns.

\section{Erkenning Mededingende belange}

Die outeur verklaar dat hy geen finansiële of persoonlike verbintenis het met enige party wat hom nadelig kon beïnvloed het in die skryf van hierdie artikel nie.

\section{Literatuurverwysings}

Behm, J., 1967, 'voćw', in G. Kittel (ed.), Theological Dictionary of the New Testament, vol. 4, pp. 948-951, transl. G.W. Bromily, William B. Eerdmans Publishing Company, Grand Rapids.

Berkhoff, L., 2009, The history of Christian doctrines, The Banner of Truth Trust Edinburgh.

Bierma, L.D., 2013, 'The History and People behind the Heidelberg Catechism', in J.D. Payne \& S. Heck (ed.), A Faith worth Teaching. The Heidelberg Catechism's Enduring Heritage, pp. 3-4, Reformation Heritage Books, Grand Rapids.

Bosman, H.L., 1987, 'Die historiese wortels van die Skrifgebruik in die Nederlandse geloofsbelydenis', in H.L. Bosman (red.), Die Nederlandse Geloofsbelydenis - Ontstaan, Skrifgebruik en Gebruik, pp. 29-52, Universiteit van Suid-Afrika, Pretoria.

Brawley, R.L., 1993, 'Discoursive structure and the unseen in Hebrews 2:8 and 11:1 A neglected aspect of the context', The Catholic Biblical Quarterly 55(1), 81-98.

Brown, C., 1990, Christianity \& Western Thought. A History of Philosophers, Ideas \& Movements:, From the Ancient World to the age of the Enlightenment, vol. 1, InterVarsity Press, Illinois.

Bruce, F.F., 1979, 'The History of New Testament Study', in I.H. Marshall (ed.), New Testament Interpretation. Essays on principles and methods, pp. 21-59, The Paternoster Press, Exeter.

Bultmann, R.K., 1968, 'The ríotıs group in the New Testament', in G. Friedrich (ed.) Theological Dictionary of the New Testament, vol. 6, pp. 203-228, transl. G.W. Bromily, William B. Eerdmans Publishing Company, Grand Rapids.

Calvyn, J., 1853, Commentaries on the book of the prophet Daniel, vol. 2, Calvin Translation Society, Edinburgh.

Calvyn, J., 1970, De Handelingen der Apostelen, W.A. de Groot, Goudriaan.

Calvyn, J., 1971, Het Evangelie van Johannes, W.A. de Groot, Goudriaan.

Calvyn, J., 1981, Calvyn se Kategismus, Potchefstroomse Teologiese Publikasies, Potchefstroom.

Calvyn, J., 1984, Institusie van die Christelike Godsdiens, boek 1, vert. H.W. Simpson, Calvyn Jubileum Boekefonds, Potchefstroom.

Calvyn, J., 1988, Institusie van die Christelike Godsdiens, boek 3, vert. H.W. Simpson, Calvyn Jubileum Boekefonds, Potchefstroom.

Clark, N., 1996, 'Reading the book. The Letter to the Hebrews', The Expository Times 108(2), 37-40. http://dx.doi.org/10.1177/001452469610800202

Coertzen, P., 1991, 'Gepas en ordelik. 'n Teologiese verantwoording van die orde vir en in die kerk', in J. Mouton (red.), RGN Studies in Metodologie, vol. 24, p. 142, RGN-Uitgewers, Pretoria.

Coetzee, J.C., 1981, Die kanon van die Ou en Nuwe Testament. Wesvalia Boekhandel, Potchefstroom.

De Graaf, S.G., 1954, Het ware geloof. Beschouwingen over Zondag 1-22 van de Heidelbergsche Catechismus, Kok, Kampen.

De Villiers, J.L, 1988, 'Die Jakobusbrief. Inleiding tot die brief van Jakobus', in A.B. du Toit (red.), Handleiding by die Nuwe Testament, Die Johannesevangelie; Hebreërs tot Openbaring. Inleiding en Teologie, band 6, pp. 113-137, NG Kerkboekhandel, Pretoria.

Dörrie, H., 1955, 'Zu Hbr. 11:1', in Zeitschrift für die Neutestamentliche Wissenschaft und die Kunde der Älteren Kirche, band 46, pp. 196-202, Verlag Alfred Töppelman, Berlin. http://dx.doi.org/10.1515/zntw.1955.46.3-4.196

Du Plooy, A. le R., 1993, 'Inleiding op die kerkorde van die Gereformeerde Kerke in Suid-Afrika, in Gereformeerde Kerke in Suid-Afrika', in N.W. Ligthelm \& H.F. van Wyk (reds.), Kerkordeboekie van die Gereformeerde Kerke in Suid-Afrika, bl. 5-11, Die Administratiewe Buro van die Gereformeerde Kerke in Suid-Afrika, Potchefstroom.

Exalto, K., s.a., De Enige Troost. Inleiding tot de Heidelbergsche Catechismus, Kok, Kampen.

Gaybba, B., 1998, 'Theology: the first 19 centuries', in S. Maimela \& A. König (eds.), Initiation into Theology. The rich variety of theology and hermeneutics, pp. 27-48, J.L. van Schaik, Pretoria.

Graafland, C., 1961, De zekerheid van het geloof. Een onderzoek naar de geloofsbeschouwing van enige vertegenwoordigers van reformatie en nadere reformatie, $\mathrm{H}$ Veenman \& Zonen N.V., Wageningen.

Graafland, C., 1973, 'Waarom nog gereformeerd?', in Van Dijk, M.P. (ed.), Theologie en Gemeente, vol. 2, bl. 92, Kok, Kampen. 
Graber, F., 1943, Der Glaubensweg des Volkes Gottes. Eine Erklärung von Hebräer 11 als Beitrag zum Verständnis des Alten Testaments, Zwingli-Verlag, Zürich.

Grässer, E., 1965, 'Der Glaube im Hebräerbrief', in H. Grass, \& W.G. Kümmel (eds.) Marburger Theologiesche Studien, vol. 2, p. 129, N.G. Elwert Verlag, Marburg.

Grosheide, F.W., 1935, 'De brief van Jakobus', in G.Ch. Aalders (ed.), Korte Verklaring der Heilige Schrift, bl. 40, Kok, Kampen.

Guthrie, D., 1981, New Testament Theology, InterVarsity Press, Leicester.

Harder, G., 1978, 'voũs', in C. Brown (ed.), The New International Dictionary of New Testament Theology, vol. 3, pp. 122-130, The Paternoster Press, Exeter.

Helberg, J.L., 1983, Verklaring en prediking van die Ou Testament, Potchefstroomse Teologiese Publikasies, Potchefstroom. PMid:6549886

Käsemann, E., 1984. The wandering people of God. An investigation of the letter to the Hebrews, transl. R.A. Harrisville \& I.L. Sandberg, Augsburg Publishing House, Minneapolis.

Kral, H., 1961, De functie van het sola fide in de Lutherse Belijdenis-geschriften, J.J. Romen \& Zonen, Roermond-Maareik.

Lane, W.L., 1991, 'Hebrews 9-13', in D.A. Hubbard, \& G.W. Barker (eds.), Word Biblical Commentary, vol. 47b, Word Books, Dallas.

Louw, J.P. \& Nida, E.A., 1988, Greek-English Lexicon of the New Testament based on semantic domains, vol. 2, Bible Society of South Africa, Kaapstad.

Michel, O., 1975, 'ríotıs', in C. Brown (ed.), The New International Dictionary of New Testament Theology, vol. 1, pp. 593-606, The Paternoster Press, Exeter.

Platt, J., 1982, 'Reformed thought and Scholasticism: The arguments for the existence of God in Dutch theology, 1575-1650', in H.A. Oberman (ed.), Studies in the History of Christian Thought, vol. 24, p. 4, E.J. Brill, Leiden.

Pont, A.D., 1983, 'Die belydenis in historiese verband', Hervormde Teologiese Studies 38(2-3), 1-29.

Oberholzer, J.P., 1986, Die Heidelbergse Kategismus in vier teksuitgawes, met inleiding en teksvergelyking. Kital, Pretoria. PMCid:PMC1338974

Runia, K., 1984, 'The hermeneutics of the reformers', Calvin Theological Journal 19 121-152.

Schulze, L.F., 1978, Geloof deur die eeue, NG Kerkboekhandel, Pretoria.

Smit, D.J., 1998, 'Biblical Hermeneutics: The first 19 centuries', in S. Maimela \& A. König (eds.), Initiation into Theology. The rich variety of theology and hermeneutics, pp. 275-296, J.L. van Schaik, Pretoria.

Spangenberg, I.J.J., 1995, 'Kritiese realisme, die Bybel, en die gereformeerde belydenisskrifte en die Christelike geloof. Kanttekeninge by ' $n$ aantal terugblikke oor die Bybelwetenskappe', Religion \& Theology 2(2), 191-205. http://dx.doi. org/10.1163/157430195X00131

Spoelstra, B., 1989, Gereformeerde Kerkreg en Kerkregering. 'n Handboek by die Kerkorde, Die Hammanskraalse Teologiese Skool van die Gereformeerde Kerke in Suid-Afrika, Hammanskraal.
Stuhlmacher, P., 1979, Vom Verstehen des Neuen Testaments: Eine Hermeneutik, Vandenhoeck und Ruprecht, Göttingen.

Swetnam, J., 1974, 'Form and content in Hebrews 7-13', Biblica 55, 333-348.

Theron, P.F., 1984, 'Persoonlike geloofsbelydenis en geloofsekerheid', in J.L. de Villiers (red.), Die kerk en sy jeug op weg, pp. 75-87, Lux Verbi, Kaapstad.

Thomas, G.H., 1961, 'Revelation, faith and doctrine: A study based on the theology of John Calvin, Friedrich Schleiermacher and Karl Barth', PhD thesis, Nashville.

Ursinus, Z., 1886, Verklaring op den Heidelbergschen Catechismus, vert. uit het Latijn C. van Proosdij, G. Ph. Zalsman, Kampen.

Ursinus, Z., 1956, The Commentary of dr. Zacharias Ursinus on the Heidelberg Catechism, transl. from the original Latin G.W. Williard, W. B. Eerdmans Publishing Company, Grand Rapids.

Van der Walt, S.P., 2001, 'Die rol van geloof in die gereformeerde hermeneuse van die Nuwe Testament as antwoord op postmodernistiese kontekstualisering', ThM verhandeling, Fakulteit Teologie, PU vir CHO.

Van der Walt, S.P., 2004, “"Ons weet omdat ons glo!” 'n Eksegetiesopenbaringshistoriese studie vanuit Hebreërs 10:38-11:3 toegepas op die problematiek van die verhouding tussen geloof en kennis', PhD-proefskrif, Fakulteit Teologie, Noordwes-Universiteit.

Van Dijk, M.P., 1980, Onze enige troost het komende Rijk. Het beleijden van de kerk in het licht van het koninkrijk der hemelen, Buijten \& Schipperheijn, Amsterdam.

Van Genderen, J., 1982, Geloofskennis en geloofsverwagting, Kok, Kampen.

Van Huyssteen, J.W.V., 1986, 'Teologie as kritiese geloofsverantwoording: Teorievorming in die sistematiese teologie', in J. Mouton (red.), RGN-studies in navorsingsmetodologie, vol. 2. Raad vir Geesteswetenskaplike Navorsing, Pretoria.

Van Niekerk, E., 1987, 'Die hermeneutiese sleutel van die Nederlandse Geloofsbelydenis', in 'H.L. Bosman (red.), Die Nederlandse Geloofsbelydenis Ontstaan, Skrifgebruik en Gebruik, pp. 14-28, UNISA, Pretoria. PMid:3657945

Van Niekerk, D.L., 1991, 'Geloof as cognitio en fiducia by Calvyn en die naReformatoriese ontwikkeling', PhD-proefskrif, Universiteit van Stellenbosch. PMCid:PMC1886195

Van Rooy, H.F., 1991, 'Die gebruik van die Ou Testament in die belydenisskrifte, hermeneuties beoordeel', In die Skriflig 25(1), 29-46.

Van Wyk, J.H., 1995, 'Die relevansie van die gereformeerde teologie vir vandag', In die Skriflig 29(1\&2), 241-268.

Van 't Spyker, W., 2009, 'The Continued Relevance of the Heidelberg Catechism', in W. van 't Spijker (ed.), The Church's Book of Comfort, Reformation Heritage Books, Grand Rapids.

Veldkamp, H., s.a., Zondagskinderen: Kantteekeningen bij den Heidelbergschen Catechismus, deel 1, T. Wever, Franeker.

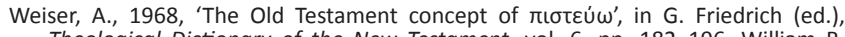
Theological Dictionary of the New Testament, vol. 6, pp. 182-196, William B. Eerdmans Publishing Company, Grand Rapids. 